\title{
UN VERDADERO POSDATA
}

\section{Carlos DECAP*}

La noticia me llegó por mail de mañana temprana como una bomba: murió Juan Zapata. Sin dar mayores detalles, Thomas Harris me contaba, el miércoles 15 de abril fatal, que Marta Contreras le había escrito esas tres tremendas palabras. Más tarde, el único consuelo que nos quedaba era que su partida había sido fulminante y no padeció como nuestro amigo Gonzalo Millán una penosa enfermedad.

Luego a la cabeza se me vinieron montones de imágenes y vivencias compartidas con Juan, sobre todo en la década de los ochenta, muchas en Concepción y otras en Santiago cuando él pasaba por allí hacia o desde los Estados Unidos, donde hacía su doctorado en literatura en la Universidad de Stony Brook.

En 1984, él se integró al cuarto número de la revista Posdata, que desde agosto de 1980 publicábamos con Harris, y de la que, en 1986, aparecería el 5-6, que sería la última entrega cuando yo ya había dejado la Ciudad Lila. Pero en 1984 no solo publicamos el primero en que participó Juan. También organizamos como Posdata, junto a la revista LAR de Omar Lara, un encuentro de escritores en el que participaron Floridor Pérez, Jaime Quezada, Jorge Narváez, Carlos Cociña, entre los que recuerdo ahora.

La actividad "cumbre" la hicimos en el auditorio de la radio de Tomé y allí conocimos al Capitán Poeta, un "paco" aficionado a la poesía, pero del que por la época uno sospechaba y hasta nos costó saludarlo de mano.

* Escritor. Profesor de español por la Universidad de Concepción. Cofundador de la revista Posdata. Es autor de los libros Asunto de ojo (1991), Golpes de vista (2005) y Asunto de ojos (2014). Trabaja en el mundo editorial como editor y corrector de estilo. Actualmente reside en Valparaíso, Chile, carlos.decap@gmail.com 
Después habría una recepción en el liceo tomecino donde el Capitán Poeta se esmeraba en atendernos con empanadas de mariscos y vasos plásticos de vino.

Muy pronto se nos hizo noche y hubo una hora en que nos subíamos al último bus a Conce, cosa que hizo el resto de la comitiva de poetas, o nos quedábamos, y eso fue lo que elegimos con Harris y Zapata. Tras bebernos otra botella de vino, quisimos hacer ingenuamente dedo, y solo pasaban vehículos de marinos vigías. Pero no faltó el tomecino "buena onda" que nos invitó primero al bar donde trabajaba su madre, que nos ofreció gratuitamente un caldo de papas, y luego nos dejó instalados en su cabaña de soltero, los tres ya bien mareados por el aire costeño.

En Santiago, aparte de haber estado varias veces en mi casa floridana, recuerdo haber hecho con Juan una visita a la residencia de Pedro Lastra, en Providencia, y encontrarnos allí con Enrique Lihn, en una de las sesiones de conversaciones que ellos tenían y que más tarde publicaría Lastra en Premiá Editores de México. También haber querido acompañarlo a ver a Lihn en su lecho de muerte, en 1988, cosa que finalmente él hizo solo, pues yo por motivos de "fuerza mayor" no pude acompañarlo.

En agosto de 2014, cuando presenté mi trilogía Asunto de ojos, en el marco del homenaje al centenario de Parra en la Escuela de Arte, de la Universidad de Concepción, no tuvimos la suerte de encontrarnos, pues él llegó, según me escribió a los pocos días en un correo, cuando ya no quedaba ni el "eco de los aplausos".

¿La última vez que lo vi? Fue en el verano del 2010, durante la presentación de la primera parte del video Poetas al cierre. Poco antes me había enviado de regalo su libro Interiores/Exteriores, así que en el post encuentro le comenté que allí había una muestra de un "verdadero Posdata", con el que compartía una educación sentimental común: libros, películas, música y mucha "meta poesía". 